\title{
Reaction of Stock Prices to Dividend Announcements and Market Efficiency in Pakistan
}

\author{
Muhammad Akbar" and Humayun Habib Baig*"
}

\begin{abstract}
This study tests the semi-strong form of market efficiency by investigating the reaction of stock prices to dividend announcements. It analyzes cash, stock, and simultaneous cash and stock dividend announcements of 79 companies listed on the Karachi Stock Exchange from July 2004 to June 2007. Abnormal returns from the market model are evaluated for statistical significance using the t-test and Wilcoxon Signed Rank Test. The findings suggest negligible abnormal returns for cash dividend announcements. However, the average abnormal and cumulative average abnormal returns for stock and simultaneous cash and stock dividend announcements are mostly positive and statistically significant.
\end{abstract}

Keywords: Stock prices, market efficiency, dividend announcements, Pakistan.

JEL Classification: G14.

\section{Introduction}

The Efficient Market Hypothesis proposed by Fama (1965) suggests three types of market efficiency: (i) weak, (ii) semi-strong, and (iii) strong. The weak form of market efficiency proposes that current stock prices reflect all past information. It also suggests that changes in stock prices are random and no investment strategy that is based on past information can yield above average returns to the investor. This implies that technical analysis will not be rewarded with above average returns. The semi-strong form of market efficiency (informational efficiency) proposes that current stock prices incorporate material public information and changes in stock prices will only lead to unexpected public information. This suggests that fundamental analysis will not be rewarded with above average returns. Finally, the strong form of market efficiency proposes that insider trading

\footnotetext{
* Assistant Professor, Department of Management Sciences, Bahria University, Islamabad.

** Master of Business Administration student, Department of Management Sciences, Bahria University, Islamabad.
} 
will not be rewarded as current stock prices incorporate all material nonpublic information (Reilly and Brown, 2008).

Market efficiency, however, does not simply occur by itself or because information is freely and timely available in the market. As Osei (1998) suggests, it depends heavily on the analytical and interpretational abilities of those who trade in the market and the time they have and are ready to devote to obtaining and spreading price-sensitive information.

The semi-strong form of market efficiency has mostly been investigated using event study methodology. Information disclosures related to dividends and earnings announcements, macroeconomic variables, stock repurchase announcements, and mergers and acquisitions, etc., have been investigated in different studies to test the semi-strong form market efficiency.

\subsection{Stock Prices, Dividends, and Semi-Strong Market Efficiency}

Although there is abundant theoretical and empirical research on the relevance of and relationship between stock prices and dividends, it is inconclusive. Graham and Dodd (1951) point toward the relevance of and hence investors' preference for dividends. Contrary to this, Miller and Modigliani (1961) propose that, in a world of no taxes and transaction costs, dividends are irrelevant to investors. However, empirical research has revealed findings that support the relevance of the dividends proposition.

In his seminal investigation of dividends policy, Lintner (1956) suggests that a firm's management will resort to increasing dividends if it believes that the increase will be permanent. Bhattacharaya (1979) explains that there exists asymmetric information between a firm's management and its shareholders: hence, an increase or decrease in dividends conveys price-sensitive information to shareholders and prospective investors. Miller and Rock (1985) and John and Williams (1985) also support the signaling or information content proposition. Brickley (1983), Healy and Palepu (1988), and Aharony and Dotan (1994) find support for the information content of dividend hypothesis, while Penman (1983) and Benartzi et al (1997) fail to do so.

Black (1976) and Easterbrook (1984) propose that dividends play a role in decreasing or increasing agency conflict between management and shareholders. When a firm's management increases dividends to shareholders, it pays out any excess cash that is left with the firm after funding all projects that have positive net present values. Therefore, positive changes in stock prices occur as a result of an increase in the dividend payout ratio and vice versa. 
Given this background on the relevance of dividend-for-stock prices, the semi-strong form of market efficiency postulates that stock prices incorporate all expected future dividends (cash and stock) and that, hence, their public announcement should not result in abnormal earnings for any investor because such dividends are fully accounted for in current stock prices. This implies that stock returns prior to the announcement data and after the announcement date should not exhibit abnormality. Therefore, both abnormal mean returns and cumulative abnormal mean returns in the event window should be statistically not different from zero. Also the semistrong form suggests that stock prices rapidly adjust to any unexpected material (in this context, unexpected increases or decreases in dividends) information.

\subsection{Dividend Announcements and Stock Returns}

One of the earliest studies in this direction was done by Pettit (1972) who found that the market made use of dividend change announcements in pricing securities. Rozeff and Kinney (1976) explain that, since firms release more information to the public in the month of January, above-normal returns in the month of January can be attributed to this increased inflow of information by firms to the market. Ball and Kothari (1991), investigating quarterly earnings announcements and stock prices in the US from 1980 to 1988, find that abnormal returns persisted after earning announcements. Gordon (1959, 1962), Foster and Vickery (1978), and Lee (1995) document evidence that suggests positive abnormal returns to dividend payment announcements. Contrary to the above studies, Easton and Sinclair (1989) find negative abnormal returns, i.e., a negative reaction by stock prices to dividend announcements; this is normally attributed to the tax effect of dividends for shareholders.

Lonie, et al (1996) investigate the dividend announcements of 620 UK companies from January to June 1991 using event study and interaction tests. They find that investors responded to the increase or decrease in dividends. However, their findings also reveal that, even for companies with no change in dividends, the average abnormal returns one day prior to the announcements were significantly different from zero as indicated by the $t$ statistic. Below and Johnson (1996) also fail to support the semi-strong form of market efficiency for the US equity market. Adelegan (2003) conducts a study to analyze the reaction of stock prices to dividend announcements and capital market efficiency in Nigeria. He uses the standard event study methodology to test the semi-strong form of market efficiency and finds that the Nigerian stock market was inefficient in its semi-strong form. 
Uddin and Chowdhury (2005) investigate dividend announcements on the Dhaka Stock Exchange and find that there were no statistically significant abnormal returns and that dividends had no information content for stock returns and prices in the Dhaka Stock Exchange. Gunasekarage and Power (2006) also find that dividend announcements influence stock returns at the time of announcements, but that the short-term influence of dividend announcements had no long-term implications. In the long run, firms with current reductions in dividends earned excess returns.

Kong and Taghavi (2006) analyze earning announcements for the Chinese equity markets. They use the M-EGARCH approach to mode1 changes in stock returns with event study methodology and reject the semistrong form of market efficiency on the basis of their findings. Acker (1999) investigates the impact of dividend announcements on stock volatility rather than stock returns and finds that stock volatility increases around dividend announcements, particularly final dividend announcement and interim dividend announcements when there is a dividend cut.

Husain (1998, 1999), Chakraborty (2006), and Ali and Akbar (2009) are a few of the studies that investigate the weak form of market efficiency in the Pakistani equity market. Ali and Mustafa (2001) examine the semistrong form of market efficiency in the Karachi Stock Exchange (KSE) by analyzing public news in two daily newspapers and the changes in trade volume and stock returns. They conclude that public information did not play an important role in the determination of stock returns since stock returns appeared more sensitive to private information.

The above literature reveals mixed findings on the semi-strong form of market efficiency and the relevance of dividends in assessing stock prices. In Pakistan, few attempts have been made to test the semi-strong form of market efficiency. Capital gains in Pakistan's equity markets are exempt from tax which cash dividends are not. Therefore, an investigation of the different types of dividend announcements and stock price reaction becomes relevant to equity markets in Pakistan. To test for market efficiency in the semi-strong form in the KSE and the relevance of dividends in pricing stocks, this study investigates stock prices and returns around 193 dividend announcements of 79 companies included in the KSE100 index from 2004 to 2007.

\section{Methodology}

The study aims to investigate the semi-strong form of market efficiency by examining the reaction of stock prices to dividend announcements using event study methodology to explore stock returns around the dividend announcement date. The announcements concern (i) 
only cash dividends, (ii) only stock dividends, and (iii) simultaneous cash and stock dividends. Therefore, we investigate the reaction of stock prices to all three types of dividend announcements and derive our conclusions concerning the level of market efficiency in its semi-strong form.

\subsection{Hypotheses}

The study investigates the following hypotheses:

$H_{1}=$ There are zero statistically significant abnormal average (positive or negative) returns $(A A B R)$ due to dividend announcements (cash, stock, and simultaneous cash and stock) in the KSE during the sample period.

$H_{2}=$ The cumulative average abnormal returns (CAABR) for all the time windows (time buckets) and types of dividend announcements considered are statistically insignificant.

$H_{3}=$ There is no statistically significant difference in the response of stock prices to different types of dividend announcements.

The null hypotheses above would imply that the KSE is efficient in its semi-strong form. Further, these would also negate the signaling (positive reaction) hypotheses of Bhattacharya (1979). The tax dividend hypothesis (which proposes that investors consider cash dividends bad because they have to pay tax on it) would also be negated. Therefore, cash dividend announcements should generate significantly negative abnormal returns.

\subsection{Sample and Data}

For this study, we use sample companies from the KSE-100 index (i.e., companies that were included among the KSE 100 index companies during the sample period) and have paid out cash dividends or bonus stocks or both at least once in the period from 1 July 2004 to 29 June 2007. A total of 79 companies out of the KSE 100 index were selected, which in all had made 193 dividend announcements during the sample period. The dividend announcements include 129 cash announcements, 24 stock announcements, and 40 simultaneous cash and stock dividend announcements. ${ }^{1}$

\footnotetext{
${ }^{1}$ Data on the dates of dividend announcements, stock prices of the companies, and KSE 100 index values was downloaded from the KSE website (www.kse.com.pk).
} 


\subsection{Procedure}

In the first part of our analysis, we use the price of each stock (i.e., stock returns) and the KSE 100 index values (i.e., market returns) for 120 days 20 days prior to the announcement day to estimate the market model:

$$
E\left(R_{i t}\right)=a_{i}+\beta_{i} R_{m t}+\mu_{i}
$$

where

$E\left(R_{i l}\right)=$ is the expected return on company $i$ stock on any given day $t$,

$\alpha_{i}=$ is the constant term,

$\beta_{i}=$ is the sensitivity of company $i$ stock to market returns $R_{m t}$.

The actual returns on each stock are calculated for the market model and 41-day window using the following formula:

$$
A R_{i t}=\left(P_{i t}-P_{i t-1}\right) / P_{i t-1}
$$

where

$A R_{i t}=$ actual returns on company $i$ stock on any given day $t$,

$P_{i t}=$ closing price of stock $i$ on any given day $t$,

$P_{i t-1}=$ closing price of stock $i$ the previous day $t-1$.

In the same manner, market returns are calculated using the following formula:

$$
R_{m t}=\left(K S E 100_{t}-K S E 100_{t-1}\right) / K S E 100_{t-1}
$$

where

$R_{m t}=$ market returns on any given day $t$,

$K S E 100_{t}=$ the KSE 100 index value on any given day $t$,

$K S E 100_{t-1}=$ the KSE 100 index value of the previous day $t-1$.

We then forecast the expected returns for 20 days prior to the announcement, the announcement day, and 20 days after the announcement 
day for each stock using the market model. Following this, abnormal returns are calculated on each of the 41 days for each stock as:

$$
A B R_{i t}=A R_{i t}-\hat{R}_{i t}
$$

where $A B R_{i t}=$ abnormal returns on company $i$ stock on any given day $t . A R_{i t}$ is the actual return on any given day $t$ for $i$ company and $\hat{R}_{i t}$ is the estimated return on company $i$ stock on any given day $t$ using market model (1). Further average daily abnormal returns for each of the 41 days are calculated for the sample as:

$$
A A B R_{t}=\sum_{i}^{n} A B R_{i t} / n
$$

where $A A B R_{t}$ is the average abnormal return on a given day and $n$ is the number of announcements made by the sample companies.

To determine the statistical significance of the $A A B R_{t}$ we use a parametric test, i.e., the $t$-test. The $t$-test utilizes the cross-sectional standard deviation of abnormal returns $\left(A B R_{t}\right)$. We also use a nonparametric test, i.e., the Wilcoxon Signed Rank Test (WCSRT) to investigate the robustness of the results for the $A A B R_{t}$. Further cumulative average abnormal returns $\left(C A A B R_{l}\right)$ are calculated as:

$$
C A A B R_{t}=\sum_{t=t_{i}}^{t_{j}} A A B R_{t}
$$

where $t_{i}$ and $t_{j}$ represent researchers' specified time windows to investigate the cumulative effect of dividend announcements on stock returns. In addition to 20 days before and after the window, we also use $(+1,-10)$, $(+10,-1),(+5,-1),(+1,-5)$ and $(+1,-1)$ time windows. These time windows have been selected to evaluate how abnormal returns behave within any of these particular time windows before and after the dividend announcement. This will enable us to identify any significant holding period over which abnormal returns might be significant. The statistical significance of $C A A B R_{t}$ is investigated in the same manner as for $A A B R_{t}$. 


\section{Empirical Results}

\subsection{Cash Dividend Announcements}

Table- 1 contains the minimum, maximum, and mean actual returns as well as standard deviations of returns for the three types of dividend announcements on each day in the event window. Table- 2 reports the AABR and CAABR for 129 cash dividend announcements for time windows of +20 days and -20 days from the announcement day. The results reveal that, except for day 6 (i.e., 0.4\%) after the announcement, the AABR is mostly statistically insignificant according to the $t$-test. However, the nonparametric WCSRT reveals that the AABR, i.e., $-0.4 \%$ on day 1 after the announcement, is significant.

Table-1: Descriptive Statistics

$$
\text { Actual Stock Returns }\left[A R_{i t}=\left(\boldsymbol{P}_{i t}-\boldsymbol{P}_{i t-1}\right) / \boldsymbol{P}_{i t-1}\right]
$$

\begin{tabular}{lcccccccccccccc}
\hline & \multicolumn{3}{c}{ Cash Dividends } & \multicolumn{3}{c}{ Stock Dividends } & \multicolumn{3}{c}{ Cash \& Stock Dividends } \\
\cline { 2 - 6 } & MIN & MAX MEAN & SD & MIN & MAX MEAN & S.D & MIN & MAX MEAN & SD \\
\hline Day -20 & -0.05 & 0.04 & 0.00 & 0.01 & -0.04 & 0.03 & 0.00 & 0.02 & -0.02 & 0.05 & 0.00 & 0.01 \\
Day -19 & -0.04 & 0.05 & 0.00 & 0.01 & -0.04 & 0.04 & 0.00 & 0.02 & -0.04 & 0.04 & 0.00 & 0.02 \\
Day -18 & -0.05 & 0.04 & 0.00 & 0.02 & -0.38 & 0.05 & -0.01 & 0.08 & -0.02 & 0.06 & 0.01 & 0.02 \\
Day -17 & -0.06 & 0.05 & 0.00 & 0.02 & -0.02 & 0.03 & 0.00 & 0.01 & -0.02 & 0.05 & 0.00 & 0.02 \\
Day -16 & -0.05 & 0.05 & 0.00 & 0.02 & -0.03 & 0.05 & 0.00 & 0.02 & -0.04 & 0.05 & 0.01 & 0.02 \\
Day -15 & -0.05 & 0.06 & 0.00 & 0.02 & -0.03 & 0.05 & 0.01 & 0.02 & -0.04 & 0.06 & 0.00 & 0.02 \\
Day -14 & -0.05 & 0.10 & 0.00 & 0.02 & -0.01 & 0.05 & 0.01 & 0.02 & -0.03 & 0.04 & 0.00 & 0.02 \\
Day -13 & -0.04 & 0.05 & 0.00 & 0.02 & -0.03 & 0.06 & 0.00 & 0.02 & -0.09 & 0.05 & 0.00 & 0.02 \\
Day -12 & -0.05 & 0.06 & 0.00 & 0.02 & -0.02 & 0.05 & 0.01 & 0.02 & -0.04 & 0.05 & 0.00 & 0.02 \\
Day -11 & -0.04 & 0.05 & 0.00 & 0.02 & -0.05 & 0.04 & 0.00 & 0.02 & -0.05 & 0.05 & 0.00 & 0.02 \\
Day -10 & -0.04 & 0.05 & 0.00 & 0.01 & -0.03 & 0.05 & 0.01 & 0.02 & -0.04 & 0.06 & 0.00 & 0.02 \\
Day -9 & -0.05 & 0.05 & 0.00 & 0.02 & -0.02 & 0.05 & 0.01 & 0.02 & -0.02 & 0.05 & 0.00 & 0.02 \\
Day -8 & -0.05 & 0.05 & 0.00 & 0.02 & -0.04 & 0.05 & 0.00 & 0.02 & -0.05 & 0.05 & 0.00 & 0.02 \\
Day -7 & -0.10 & 0.06 & 0.00 & 0.02 & -0.02 & 0.05 & 0.00 & 0.02 & -0.05 & 0.05 & 0.00 & 0.02 \\
Day -6 & -0.04 & 0.05 & 0.00 & 0.02 & -0.02 & 0.05 & 0.00 & 0.02 & -0.05 & 0.05 & 0.00 & 0.02 \\
Day -5 & -0.04 & 0.05 & 0.00 & 0.02 & -0.01 & 0.06 & 0.01 & 0.02 & -0.05 & 0.05 & 0.00 & 0.02 \\
Day -4 & -0.04 & 0.06 & 0.00 & 0.02 & -0.06 & 0.06 & 0.00 & 0.03 & -0.04 & 0.05 & 0.01 & 0.02
\end{tabular}




\begin{tabular}{rcccccccccccc} 
Day -3 & -0.05 & 0.06 & 0.00 & 0.02 & -0.05 & 0.05 & 0.01 & 0.03 & -0.05 & 0.05 & 0.01 & 0.02 \\
Day -2 & -0.06 & 0.05 & 0.00 & 0.02 & -0.04 & 0.05 & 0.00 & 0.02 & -0.05 & 0.05 & 0.00 & 0.02 \\
Day -1 & -0.05 & 0.05 & 0.00 & 0.02 & -0.05 & 0.06 & 0.00 & 0.02 & -0.05 & 0.05 & 0.01 & 0.03 \\
Day 0 & $-\mathbf{0 . 0 6}$ & $\mathbf{0 . 0 6}$ & $\mathbf{0 . 0 0}$ & $\mathbf{0 . 0 3}$ & $-\mathbf{0 . 0 6}$ & $\mathbf{0 . 0 6}$ & $\mathbf{0 . 0 1}$ & $\mathbf{0 . 0 3}$ & -0.05 & $\mathbf{0 . 0 5}$ & $\mathbf{0 . 0 2}$ & $\mathbf{0 . 0 3}$ \\
Day 1 & -0.09 & 0.13 & 0.00 & 0.03 & -0.03 & 0.05 & 0.02 & 0.03 & -0.06 & 0.08 & 0.00 & 0.03 \\
Day 2 & -0.09 & 0.07 & 0.00 & 0.02 & -0.04 & 0.05 & 0.01 & 0.03 & -0.05 & 0.10 & 0.00 & 0.03 \\
Day 3 & -0.11 & 0.05 & 0.00 & 0.02 & -0.04 & 0.05 & 0.00 & 0.03 & -0.05 & 0.21 & 0.00 & 0.04 \\
Day 4 & -0.05 & 0.05 & 0.00 & 0.02 & -0.04 & 0.05 & 0.01 & 0.02 & -0.05 & 0.06 & 0.00 & 0.02 \\
Day 5 & -0.05 & 0.07 & 0.00 & 0.02 & -0.03 & 0.06 & 0.00 & 0.02 & -0.02 & 0.05 & 0.01 & 0.02 \\
Day 6 & -0.05 & 0.06 & 0.00 & 0.02 & -0.02 & 0.05 & 0.01 & 0.02 & -0.05 & 0.06 & 0.00 & 0.02 \\
Day 7 & -0.05 & 0.05 & 0.00 & 0.02 & -0.02 & 0.05 & 0.01 & 0.02 & -0.05 & 0.05 & 0.00 & 0.02 \\
Day 8 & -0.05 & 0.09 & 0.00 & 0.02 & -0.05 & 0.04 & 0.00 & 0.02 & -0.04 & 0.05 & 0.00 & 0.02 \\
Day 9 & -0.05 & 0.05 & 0.00 & 0.02 & -0.03 & 0.04 & 0.00 & 0.02 & -0.02 & 0.05 & 0.00 & 0.02 \\
Day 10 & -0.09 & 0.05 & 0.00 & 0.02 & -0.05 & 0.04 & 0.00 & 0.02 & -0.21 & 0.10 & 0.00 & 0.05 \\
Day 11 & -0.04 & 0.05 & 0.00 & 0.02 & -0.02 & 0.04 & 0.00 & 0.02 & -0.05 & 0.05 & 0.00 & 0.02 \\
Day 12 & -0.04 & 0.05 & 0.00 & 0.02 & -0.28 & 0.03 & -0.02 & 0.06 & -0.20 & 0.05 & 0.00 & 0.04 \\
Day 13 & -0.10 & 0.05 & 0.00 & 0.02 & -0.04 & 0.05 & 0.00 & 0.02 & -0.18 & 0.04 & -0.01 & 0.04 \\
Day 14 & -0.07 & 0.06 & 0.00 & 0.02 & -0.39 & 0.07 & -0.02 & 0.09 & -0.25 & 0.03 & -0.02 & 0.06 \\
Day 15 & -0.06 & 0.05 & 0.00 & 0.02 & -0.55 & 0.05 & -0.03 & 0.12 & -0.17 & 0.05 & -0.01 & 0.04 \\
Day 16 & -0.44 & 0.05 & -0.01 & 0.04 & -0.33 & 0.02 & -0.02 & 0.07 & -0.24 & 0.04 & -0.03 & 0.07 \\
Day 17 & -0.06 & 0.05 & 0.00 & 0.02 & -0.27 & 0.02 & -0.02 & 0.06 & -0.27 & 0.05 & -0.02 & 0.05 \\
Day 18 & -0.09 & 0.05 & 0.00 & 0.02 & -0.13 & 0.05 & -0.01 & 0.03 & -0.19 & 0.05 & -0.02 & 0.05 \\
Day 19 & -0.05 & 0.05 & 0.00 & 0.02 & -0.17 & 0.05 & -0.01 & 0.05 & -0.41 & 0.05 & -0.03 & 0.09 \\
n & & $\mathbf{1 2 9}$ & & & & $\mathbf{2 4}$ & & & & $\mathbf{4 0}$ & \\
\hline & & & & & & & & & & & &
\end{tabular}

The lower part of Table- 2 reports the CAABR for the alternative time windows considered. It indicates that the CAABR for the time windows of +1 day, -1 day $(-0.9 \%)$ and +5 day, and -1 day $(-1.4 \%)$ after the announcement is negative and statistically significant. Therefore, the returns for these two time windows reveal that the market fails to fully anticipate public information as both time windows report statistically significant abnormal returns.

The general conclusion drawn from the analysis of the AABR and CAABR for cash dividend announcements is that both are insignificant. 
Table-2: $t$-Test Results (Cash Dividend Announcements, $n=129$ )

\begin{tabular}{lccccccc}
\hline & & & $\boldsymbol{t}$-Test & WCSRT & \multicolumn{2}{c}{$\boldsymbol{t}$-Test } & \multicolumn{1}{l}{ WCSRT } \\
\hline & AABR & S.D & t & Z & CAABR & t & Z \\
\hline Day -20 & -0.002 & 0.015 & -1.445 & -2.527 & -0.002 & -1.445 & -2.527 \\
Day -19 & 0.001 & 0.015 & 0.469 & -0.408 & -0.001 & -0.724 & -1.420 \\
Day -18 & 0.000 & 0.018 & 0.096 & -0.457 & -0.001 & -0.483 & -1.095 \\
Day -17 & 0.002 & 0.017 & 1.549 & -0.385 & 0.001 & 0.456 & -0.035 \\
Day -16 & -0.001 & 0.018 & -0.578 & -1.244 & 0.000 & 0.110 & -0.069 \\
Day -15 & -0.001 & 0.016 & -0.820 & -1.330 & -0.001 & -0.264 & -0.040 \\
Day -14 & 0.003 & 0.017 & 1.718 & -0.971 & 0.002 & 0.491 & -0.577 \\
Day -13 & 0.003 & 0.016 & 1.961 & -0.728 & 0.005 & 1.180 & -0.890 \\
Day -12 & 0.001 & 0.018 & 0.698 & -0.300 & 0.006 & 1.314 & -0.976 \\
Day -11 & 0.001 & 0.017 & 0.957 & -0.170 & 0.007 & 1.615 & -1.212 \\
Day -10 & -0.002 & 0.013 & -1.369 & -1.913 & 0.006 & 1.232 & -0.931 \\
Day -9 & 0.000 & 0.018 & 0.200 & -0.708 & 0.006 & 1.239 & -1.149 \\
Day -8 & 0.000 & 0.019 & 0.164 & -0.207 & 0.006 & 1.146 & -1.043 \\
Day -7 & 0.002 & 0.021 & 0.859 & -0.300 & 0.008 & 1.299 & -1.215 \\
Day -6 & 0.001 & 0.018 & 0.695 & -0.088 & 0.009 & 1.345 & -1.106 \\
Day -5 & 0.002 & 0.019 & 1.357 & -0.336 & 0.011 & 1.569 & -1.355 \\
Day -4 & 0.002 & 0.019 & 1.248 & -0.227 & 0.013 & 1.739 & -1.476 \\
Day -3 & 0.000 & 0.022 & 0.039 & -0.454 & 0.013 & 1.661 & -1.403 \\
Day -2 & 0.003 & 0.018 & 1.942 & -1.399 & 0.016 & 1.939 & -1.625 \\
Day -1 & -0.001 & 0.020 & -0.305 & -1.113 & 0.016 & 1.868 & -1.446 \\
Day0 & -0.005 & 0.028 & -1.887 & -1.806 & 0.011 & 1.316 & -0.824 \\
Day1 & -0.004 & 0.026 & -1.797 & -2.730 & 0.007 & 0.764 & -0.139 \\
Day2 & -0.003 & 0.024 & -1.200 & -1.563 & 0.004 & 0.464 & -0.060 \\
Day3 & -0.003 & 0.022 & -1.580 & -1.787 & 0.001 & 0.139 & -0.342 \\
Day4 & -0.001 & 0.018 & -0.422 & -1.068 & 0.001 & 0.066 & -0.222 \\
Day5 & 0.002 & 0.020 & 0.999 & -0.168 & 0.002 & 0.251 & -0.035 \\
Day6 & 0.004 & 0.017 & 2.527 & -1.799 & 0.006 & 0.633 & -0.245 \\
Day7 & 0.003 & 0.019 & 1.560 & -0.937 & 0.009 & 0.873 & -0.475
\end{tabular}




\begin{tabular}{llllllll} 
Day8 & 0.000 & 0.020 & -0.152 & -0.987 & 0.008 & 0.820 & -0.416 \\
Day9 & 0.001 & 0.019 & 0.621 & -0.226 & 0.010 & 0.892 & -0.579 \\
Day10 & -0.001 & 0.019 & -0.605 & -1.462 & 0.009 & 0.796 & -0.435 \\
Day11 & -0.001 & 0.017 & -0.416 & -1.574 & 0.008 & 0.720 & -0.227 \\
Day12 & 0.001 & 0.017 & 0.607 & -0.850 & 0.009 & 0.788 & -0.241 \\
Day13 & -0.001 & 0.020 & -0.526 & -0.537 & 0.008 & 0.704 & -0.142 \\
Day14 & -0.001 & 0.020 & -0.793 & -0.590 & 0.007 & 0.572 & -0.049 \\
Day15 & 0.002 & 0.020 & 1.384 & -1.291 & 0.009 & 0.751 & -0.210 \\
Day16 & -0.006 & 0.045 & -1.490 & -1.184 & 0.003 & 0.266 & -0.102 \\
Day17 & 0.002 & 0.019 & 1.346 & -0.948 & 0.005 & 0.451 & -0.099 \\
Day18 & 0.001 & 0.021 & 0.722 & -1.090 & 0.007 & 0.536 & -0.229 \\
Day19 & 0.001 & 0.019 & 0.308 & -0.261 & 0.007 & 0.571 & -0.360 \\
Day20 & -0.003 & 0.025 & -1.456 & -1.006 & 0.004 & 0.313 & -0.058 \\
CAABR(+1,-1) & -0.009 & 0.0469 & -2.27 & -2.29 & - & - & - \\
CAABR(-5,+1) & -0.002 & 0.0623 & -0.35 & -0.51 & - & - & - \\
CAABR(+5,-1) & -0.014 & 0.0636 & -2.48 & -2.58 & - & - & - \\
CAABR(-10,+1) & 0.000 & 0.0810 & -0.03 & -0.70 & - & - & - \\
CAABR(+10,-1) & -0.008 & 0.0868 & -1.01 & -1.36 & - & - & - \\
\hline
\end{tabular}

$*$ and $* *$ indicate significance at $1 \%$ and $5 \%$, respectively.

\section{Figure-1: CAABR Graph for Cash Dividend Announcements}

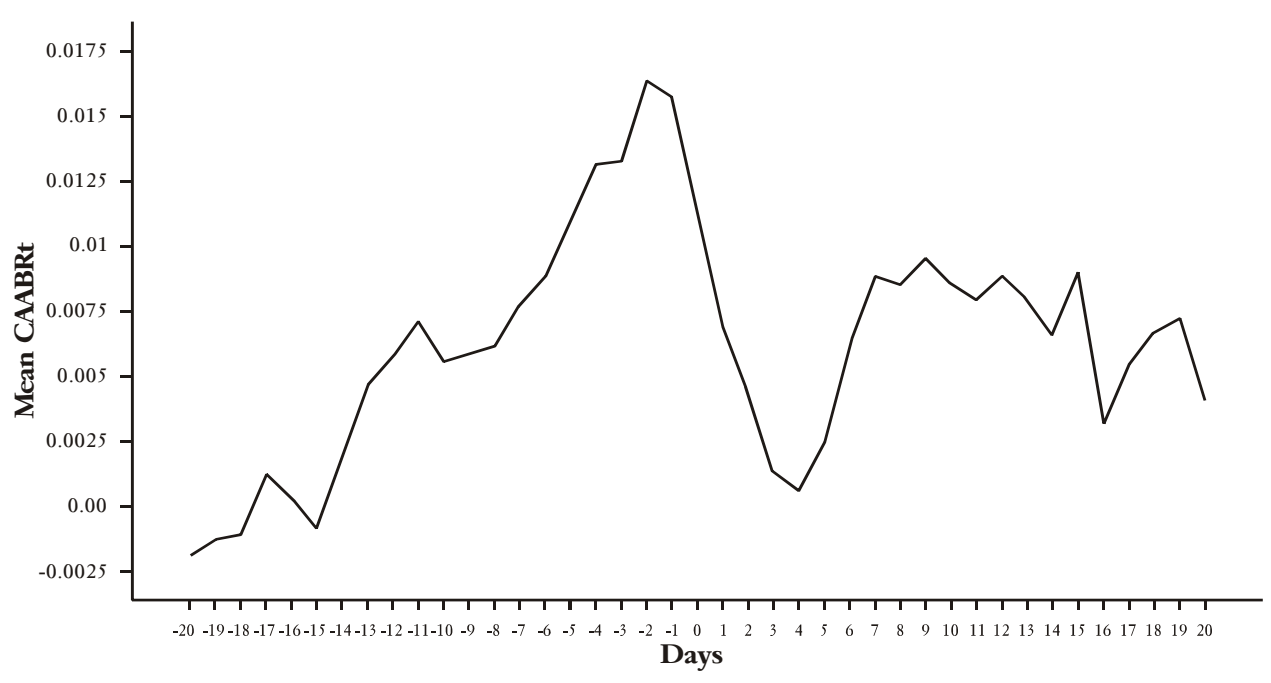


Furthermore, the $t$-values and $z$-values reported in the lower part of Table-3 are statistically significant for the CAABR for all the alternative time windows considered. A CAABR of $6.4 \%$ is reported for time windows of -10 days, +1 day and +10 days, and -1 day. This supports the argument that the $\mathrm{KSE}$ is inefficient in its semi-strong form. It also reveals that the value created by stock dividends is lost very quickly once the stock becomes exdividend. However, consideration must be given to the sample size (the number of stock dividend announcements, i.e., 24) which is small.

Table-3: $t$-Test Results (Stock Dividend Announcements, $\mathrm{n}=24$ )

\begin{tabular}{|c|c|c|c|c|c|c|c|}
\hline & & & $t$ Test & WCSRT & $t \mathrm{~T}$ & & WCSRT \\
\hline & AABR & SD & $t$ & $\mathbf{Z}$ & CAABR & $t$ & $\mathrm{Z}$ \\
\hline Day -20 & -0.005 & 0.017 & -1.375 & -1.172 & -0.005 & -1.375 & -1.172 \\
\hline Day -19 & -0.002 & 0.024 & -0.354 & -0.400 & -0.007 & -1.094 & -1.086 \\
\hline Day -18 & -0.011 & 0.080 & -0.650 & -1.100 & -0.017 & -0.963 & -0.443 \\
\hline Day -17 & 0.005 & 0.012 & 1.869 & -1.714 & -0.012 & -0.729 & -0.157 \\
\hline Day -16 & 0.001 & 0.018 & 0.396 & -0.486 & -0.011 & -0.678 & -0.171 \\
\hline Day -15 & 0.009 & 0.022 & 2.001 & -1.686 & -0.002 & -0.115 & -1.300 \\
\hline Day -14 & 0.012 & 0.020 & 2.768 & -2.200 & 0.009 & 0.466 & -1.686 \\
\hline Day -13 & 0.004 & 0.022 & 0.998 & -0.157 & 0.014 & 0.634 & -1.629 \\
\hline Day -12 & 0.006 & 0.020 & 1.463 & -1.000 & 0.020 & 0.836 & -1.543 \\
\hline Day -11 & 0.002 & 0.023 & 0.514 & -0.343 & 0.022 & 0.861 & -1.371 \\
\hline Day -10 & 0.006 & 0.022 & 1.366 & -0.914 & 0.028 & 1.057 & -1.286 \\
\hline Day -9 & 0.006 & 0.025 & 1.140 & -0.371 & 0.034 & 1.208 & -1.086 \\
\hline Day -8 & 0.000 & 0.020 & -0.047 & -0.486 & 0.034 & 1.250 & -1.143 \\
\hline Day -7 & 0.004 & 0.019 & 1.015 & -0.557 & 0.038 & 1.444 & -1.257 \\
\hline Day -6 & 0.002 & 0.022 & 0.442 & -0.429 & 0.040 & 1.441 & -1.129 \\
\hline Day -5 & 0.012 & 0.021 & 2.852 & -2.272 & 0.052 & 1.810 & -1.629 \\
\hline Day -4 & 0.001 & 0.028 & 0.173 & -0.271 & 0.053 & 1.769 & -1.243 \\
\hline Day -3 & 0.006 & 0.026 & 1.161 & -0.971 & 0.059 & 1.996 & -1.657 \\
\hline Day -2 & 0.001 & 0.020 & 0.238 & -0.400 & 0.060 & 1.998 & -1.686 \\
\hline Day -1 & 0.000 & 0.024 & 0.054 & -0.257 & 0.060 & 2.128 & -1.943 \\
\hline Day0 & 0.008 & 0.035 & 1.101 & -1.071 & 0.068 & 2.396 & -2.114 \\
\hline Day1 & 0.018 & 0.028 & 3.246 & -2.631 & 0.086 & 2.765 & -2.571 \\
\hline Day2 & 0.011 & 0.031 & 1.799 & -1.657 & 0.098 & 2.843 & -2.429 \\
\hline Day3 & 0.003 & 0.027 & 0.573 & -0.365 & 0.101 & 2.779 & -2.314 \\
\hline Day4 & 0.005 & 0.025 & 1.003 & -0.571 & 0.106 & 2.799 & -2.343 \\
\hline Day 5 & 0.004 & 0.022 & 0.882 & -0.429 & 0.110 & 2.829 & -2.286 \\
\hline
\end{tabular}




\begin{tabular}{lccccccc} 
Day6 & 0.012 & 0.020 & $\mathbf{2 . 9 8 9}$ & $\mathbf{- 2 . 4 2 9}$ & 0.122 & $\mathbf{2 . 9 9 6}$ & $\mathbf{- 2 . 4 5 7}$ \\
Day7 & 0.005 & 0.019 & 1.338 & -0.900 & 0.127 & 2.977 & $\mathbf{- 2 . 4 8 6}$ \\
Day8 & -0.002 & 0.023 & -0.475 & -0.086 & 0.125 & 2.904 & $\mathbf{- 2 . 4 5 7}$ \\
Day9 & -0.002 & 0.015 & -0.485 & -0.872 & 0.123 & $\mathbf{2 . 8 5 1}$ & $\mathbf{- 2 . 3 4 3}$ \\
Day10 & 0.000 & 0.017 & 0.139 & -0.543 & 0.124 & 2.873 & $\mathbf{- 2 . 3 1 4}$ \\
Day11 & 0.004 & 0.017 & 1.259 & -0.957 & 0.128 & 2.985 & $\mathbf{- 2 . 4 2 9}$ \\
Day12 & -0.015 & 0.060 & -1.241 & -1.371 & 0.113 & $\mathbf{2 . 7 1 0}$ & $\mathbf{- 2 . 2 0 0}$ \\
Day13 & 0.002 & 0.020 & 0.584 & -0.608 & 0.115 & $\mathbf{2 . 6 6 6}$ & $\mathbf{- 2 . 2 2 9}$ \\
Day14 & -0.018 & 0.088 & -0.977 & -0.171 & 0.098 & 2.257 & -1.886 \\
Day15 & -0.034 & 0.123 & -1.355 & -0.400 & 0.064 & 1.205 & -1.086 \\
Day16 & -0.021 & 0.074 & -1.393 & -0.757 & 0.043 & 0.770 & -0.629 \\
Day17 & -0.015 & 0.056 & -1.349 & -1.486 & 0.028 & 0.465 & -0.371 \\
Day18 & -0.006 & 0.034 & -0.812 & -0.543 & 0.022 & 0.372 & -0.414 \\
Day19 & -0.008 & 0.052 & -0.758 & -0.057 & 0.014 & 0.241 & -0.200 \\
Day20 & -0.005 & 0.027 & -0.958 & -1.457 & 0.009 & 0.147 & -0.229 \\
\hline CAABR(+1,-1) & 0.026 & 0.0443 & 2.91 & -2.57 & - & - & - \\
CAABR(-5,+1) & 0.047 & 0.0781 & 2.93 & -2.60 & - & - & - \\
CAABR(+5,-1) & 0.050 & 0.1004 & 2.43 & -2.14 & - & - & - \\
CAABR(-10,+1) & 0.064 & 0.1060 & $\mathbf{2 . 9 7}$ & $\mathbf{- 2 . 5 4}$ & - & - & - \\
CAABR(+10,-1) & 0.064 & 0.1093 & $\mathbf{2 . 8 6}$ & $\mathbf{- 2 . 4 9}$ & - & - & - \\
\hline
\end{tabular}

$*$ and $* *$ indicate significance at $1 \%$ and $5 \%$, respectively.

Figure-2: CAABR Graph for Stock Dividend Announcements

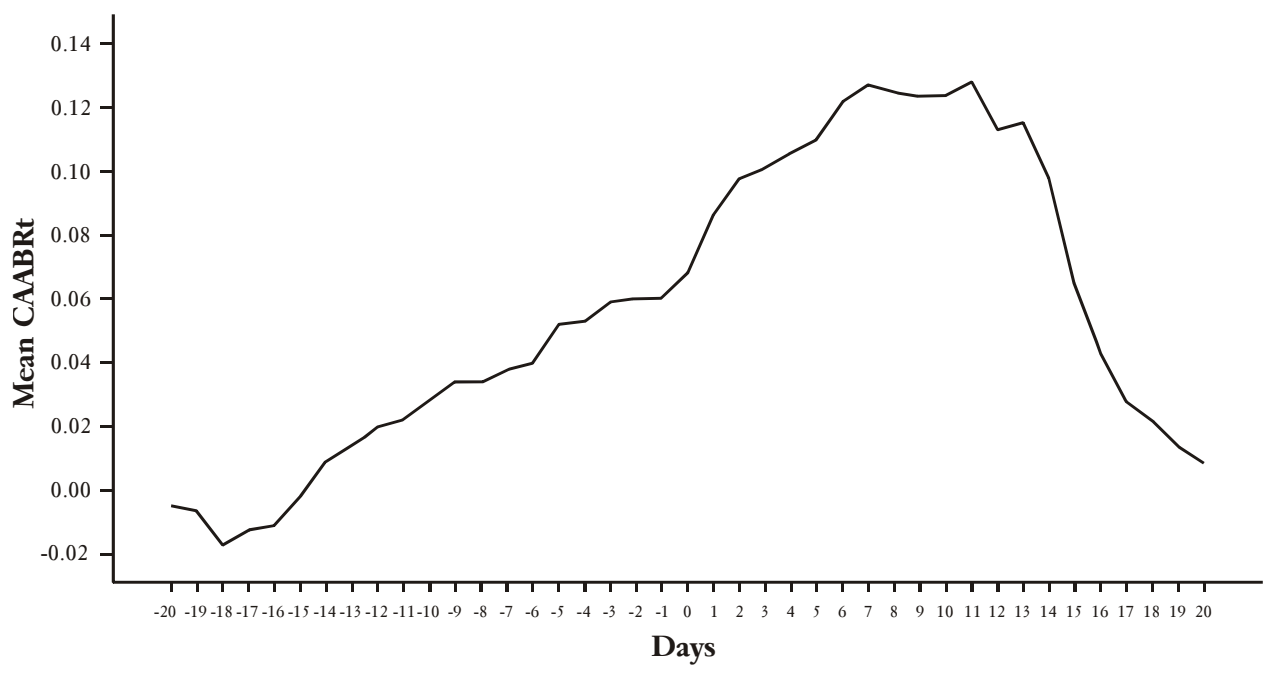




\subsection{Stock Dividend Announcements}

The AABR and CAABR of 24 stock dividend announcements for time windows of +20 days and -20 days are reported in Table- 3 . The table reveals that the AABR on day $5(1.2 \%)$ and day 14 (1.2\%) before, and day $1(1.8 \%)$ and day $6(1.2 \%)$ after the announcements are positive and statistically significant according to both the $t$-test and WCSRT. Since semi-strong market efficiency implies that stock returns should not exhibit abnormal returns both before and after the announcement, these abnormalities suggest a violation of the semi-strong form of market efficiency. Any reaction by the market should be instantaneous and the adjustment process should be rapid; hence, if there are any adjustments, they must occur instantaneously. The CAABR is also statistically significant from day 1 before the announcement until day 14 after the announcement. This suggests that the KSE is inefficient in its semi-strong form as revealed by the reaction of stock prices (returns) around the dividend announcement.

\subsection{Cash and Stock Dividend Announcements}

Table- 4 contains the AABR and CAABR for 40 simultaneous cash and stock dividend announcements for a time window of +20 days, -20 days, and the announcement day. The $t$-values and $z$-values reveal that the AABR on day 4 before and day 5 after the announcement of a simultaneous cash and stock dividend is significantly different from zero and is positive. Further, the $\mathrm{AABR}$ on the announcement day is positive and statistically significant.

The AABR on the announcement day is $2.1 \%$. However, the AABRs for days $14,16,17,18$, and 19 are negative and statistically significant. The CAABR from day 3 before the announcement till day 13 after the announcement is statistically significant and positive. This reveals that dividends result in short-term abnormal returns which accrue only up to the ex-dividend date. Once the stock becomes ex-dividend, stock prices fall and result in negative returns. The abnormal returns reported in this case are lower in value than reported for the stock dividend announcements in Table-3.

The CAABR for all five alternative time windows are reported in the lower part of Table-4. It shows that the returns (i.e. CAABR) for the five time windows are positive and statistically significant. The highest CAABR is $8.2 \%$, reported for a time window of +5 days and -1 day. 
Table-4: $t$-Test Results (Both Cash and Stock Dividend Announcements, $\mathrm{n}=40$ )

\begin{tabular}{|c|c|c|c|c|c|c|c|}
\hline & & & $t$ Test & WCSRT & $t \mathbf{T}$ & & WCSRT \\
\hline & AABR & S.D & $t$ & $\bar{Z}$ & CAABR & $t$ & $\bar{Z}$ \\
\hline Day -20 & -0.001 & 0.015 & -0.471 & -1.331 & -0.001 & -0.471 & -1.331 \\
\hline Day -19 & -0.002 & 0.016 & -0.926 & -1.042 & -0.003 & -1.154 & -1.493 \\
\hline Day -18 & 0.005 & 0.017 & 1.872 & -1.122 & 0.002 & 0.433 & -0.094 \\
\hline Day -17 & 0.002 & 0.017 & 0.770 & -0.524 & 0.004 & 0.748 & -0.040 \\
\hline Day -16 & 0.005 & 0.020 & 1.648 & -0.948 & 0.009 & 1.388 & -0.854 \\
\hline Day -15 & 0.003 & 0.022 & 0.927 & -0.457 & 0.012 & 1.497 & -1.048 \\
\hline Day -14 & 0.004 & 0.018 & 1.274 & -0.645 & 0.016 & 1.761 & -1.384 \\
\hline Day -13 & 0.000 & 0.023 & 0.104 & -0.148 & 0.016 & 1.644 & -1.425 \\
\hline Day -12 & 0.001 & 0.020 & 0.423 & -0.094 & 0.018 & 1.723 & -1.505 \\
\hline Day -11 & 0.000 & 0.024 & 0.011 & -0.232 & 0.018 & 1.566 & -1.411 \\
\hline Day -10 & 0.000 & 0.021 & 0.014 & -0.628 & 0.018 & 1.328 & -1.055 \\
\hline Day -9 & 0.003 & 0.019 & 1.034 & -0.255 & 0.021 & 1.426 & -1.055 \\
\hline Day -8 & 0.000 & 0.021 & 0.070 & -0.155 & 0.021 & 1.255 & -0.954 \\
\hline Day -7 & -0.002 & 0.022 & -0.583 & -1.035 & 0.019 & 1.028 & -0.686 \\
\hline Day -6 & 0.003 & 0.021 & 0.802 & -0.625 & 0.022 & 1.159 & -0.995 \\
\hline Day -5 & 0.002 & 0.019 & 0.776 & -0.551 & 0.024 & 1.298 & -1.465 \\
\hline Day -4 & 0.012 & 0.022 & 3.408 & -3.024 & 0.036 & 1.842 & -1.902 \\
\hline Day -3 & 0.007 & 0.024 & 1.766 & -1.458 & 0.042 & 2.066 & -2.272 \\
\hline Day -2 & 0.001 & 0.025 & 0.252 & -0.007 & 0.043 & 2.088 & -2.057 \\
\hline Day -1 & 0.005 & 0.027 & 1.204 & -0.934 & 0.048 & 2.257 & -2.312 \\
\hline Day0 & 0.021 & 0.029 & 4.657 & -3.616 & 0.070 & 3.120 & -3.065 \\
\hline Day1 & 0.003 & 0.032 & 0.620 & -0.188 & 0.073 & 3.070 & -2.695 \\
\hline Day2 & 0.003 & 0.033 & 0.587 & -0.279 & 0.076 & 2.889 & -2.339 \\
\hline Day3 & 0.004 & 0.041 & 0.647 & -0.222 & 0.080 & 3.018 & -2.473 \\
\hline Day4 & 0.001 & 0.023 & 0.280 & -0.223 & 0.081 & 2.977 & -2.547 \\
\hline Day 5 & 0.009 & 0.020 & 3.034 & -2.339 & 0.090 & 3.215 & -2.742 \\
\hline Day6 & 0.002 & 0.020 & 0.494 & -0.269 & 0.092 & 3.151 & -2.742 \\
\hline Day7 & -0.002 & 0.018 & -0.577 & -0.679 & 0.090 & 3.118 & -2.661 \\
\hline Day8 & 0.002 & 0.018 & 0.575 & -0.161 & 0.092 & 3.197 & -2.635 \\
\hline
\end{tabular}




\begin{tabular}{lccccccc} 
Day9 & 0.005 & 0.016 & 1.742 & -1.304 & 0.097 & 3.242 & -2.661 \\
Day10 & -0.004 & 0.048 & -0.570 & -0.329 & 0.092 & 3.099 & -2.534 \\
Day11 & 0.001 & 0.022 & 0.304 & -0.390 & 0.093 & 3.026 & -2.379 \\
Day12 & 0.000 & 0.037 & 0.032 & -1.425 & 0.093 & 2.990 & -2.487 \\
Day13 & -0.008 & 0.036 & -1.398 & -1.015 & 0.085 & 2.765 & -2.352 \\
Day14 & -0.022 & 0.058 & -2.369 & -2.272 & 0.064 & 1.910 & -1.579 \\
Day15 & -0.009 & 0.038 & -1.545 & -1.425 & 0.054 & 1.609 & -1.304 \\
Day16 & -0.031 & 0.073 & -2.660 & -2.178 & 0.023 & 0.655 & -0.040 \\
Day17 & -0.017 & 0.054 & -2.041 & -2.043 & 0.006 & 0.158 & -0.363 \\
Day18 & -0.019 & 0.054 & -2.197 & -2.245 & -0.013 & -0.333 & -0.941 \\
Day19 & -0.030 & 0.092 & -2.040 & -1.801 & -0.042 & -1.097 & -1.734 \\
Day20 & -0.010 & 0.044 & -1.408 & -1.807 & -0.052 & -1.415 & -1.707 \\
\hline CAABR(+1,-1) & 0.030 & 0.0623 & 3.14 & -2.92 & - & - & - \\
CAABR(-5,+1) & 0.054 & 0.0885 & 3.98 & -3.37 & - & - & - \\
CAABR(+5,-1) & 0.082 & 0.2490 & $\mathbf{2 . 1 3}$ & -2.67 & - & - & - \\
CAABR(-10,+1) & 0.059 & 0.1219 & 3.15 & -2.84 & - & - & - \\
CAABR(+10,-1) & 0.059 & 0.1512 & $\mathbf{2 . 5 1}$ & $\mathbf{- 2 . 1 8}$ & - & - & - \\
\hline
\end{tabular}

* and $* *$ indicate significance at $1 \%$ and $5 \%$, respectively.

\section{Figure-3: CAABR for Simultaneous Cash and Stock Dividend}

\section{Announcements}

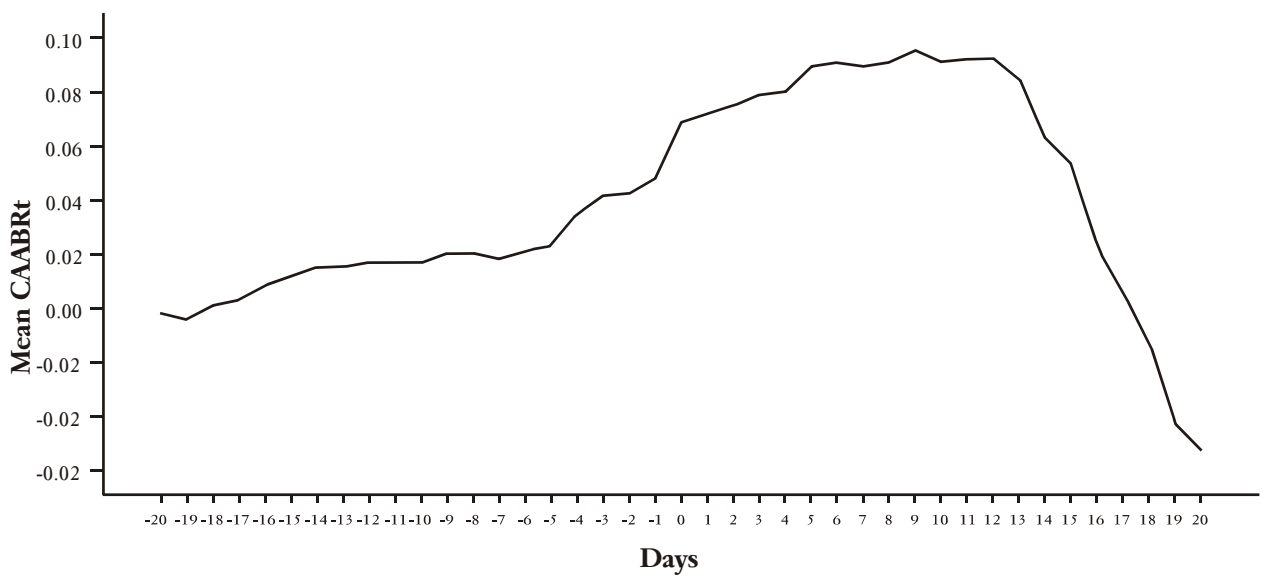

To establish whether stock prices react differently to cash, stock, and simultaneous cash and stock dividends, we conducted a one-way ANOVA for all the 41 days' AABR for the entire sample, divided into three groups. Table-5 reports the results for those days on which the F-test 
indicates that at least the returns of one sample group are significantly different from that of other sample groups. This suggests that investors react differently to different types of dividend announcements when quoting the prices of stocks expected to pay dividends.

Figure-4: ANOVA (1. Cash, 2. Stock, 3. Cash and Stock)
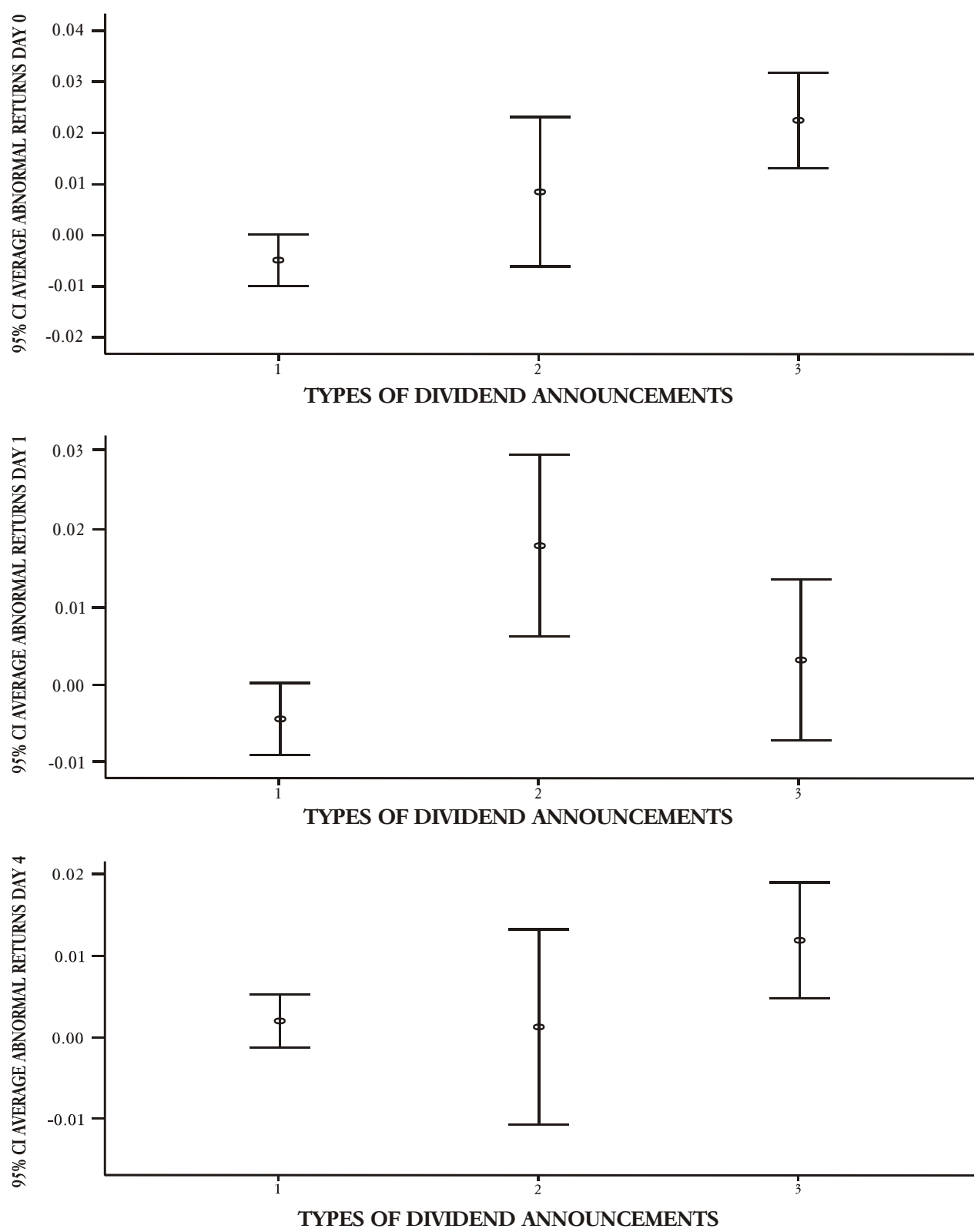
Table-5: ANOVA Test

\begin{tabular}{|c|c|c|c|c|c|c|}
\hline & & SS & df & MS & $\mathbf{F}$ & Sig. \\
\hline \multirow[t]{3}{*}{ AAR DAY-15 } & Between Groups & 0.0030 & 2 & 0.0015 & 4.30 & $0.01 * *$ \\
\hline & Within Groups & 0.0670 & 190 & 0.0004 & & \\
\hline & Total & 0.0701 & 192 & & & \\
\hline \multirow[t]{3}{*}{ AAR DAY-4 } & Between Groups & 0.0032 & 2 & 0.0016 & 3.61 & $0.03 * *$ \\
\hline & Within Groups & 0.0856 & 190 & 0.0005 & & \\
\hline & Total & 0.0888 & 192 & & & \\
\hline \multirow[t]{3}{*}{ AAR DAY 0} & Between Groups & 0.0237 & 2 & 0.0119 & 13.33 & $0.00 *$ \\
\hline & Within Groups & 0.1693 & 190 & 0.0009 & & \\
\hline & Total & 0.1930 & 192 & & & \\
\hline \multirow[t]{3}{*}{ AAR DAY 1} & Between Groups & 0.0106 & 2 & 0.0053 & 6.77 & $0.00^{*}$ \\
\hline & Within Groups & 0.1482 & 190 & 0.0008 & & \\
\hline & Total & 0.1588 & 192 & & & \\
\hline \multirow[t]{3}{*}{ AAR DAY 14} & Between Groups & 0.0160 & 2 & 0.0080 & 4.21 & $0.02 * *$ \\
\hline & Within Groups & 0.3604 & 190 & 0.0019 & & \\
\hline & Total & 0.3764 & 192 & & & \\
\hline \multirow[t]{3}{*}{ AAR DAY15 } & Between Groups & 0.0276 & 2 & 0.0138 & 5.83 & $0.00^{*}$ \\
\hline & Within Groups & 0.4499 & 190 & 0.0024 & & \\
\hline & Total & 0.4775 & 192 & & & \\
\hline \multirow[t]{3}{*}{ AAR DAY 16} & Between Groups & 0.0220 & 2 & 0.0110 & 3.47 & $0.03^{* *}$ \\
\hline & Within Groups & 0.6021 & 190 & 0.0032 & & \\
\hline & Total & 0.6241 & 192 & & & \\
\hline \multirow[t]{3}{*}{ AAR DAY 17} & Between Groups & 0.0160 & 2 & 0.0080 & 6.36 & $0.00 *$ \\
\hline & Within Groups & 0.2396 & 190 & 0.0013 & & \\
\hline & Total & 0.2556 & 192 & & & \\
\hline \multirow[t]{3}{*}{ AAR DAY 18} & Between Groups & 0.0127 & 2 & 0.0063 & 6.15 & $0.00 *$ \\
\hline & Within Groups & 0.1954 & 190 & 0.0010 & & \\
\hline & Total & 0.2081 & 192 & & & \\
\hline \multirow[t]{3}{*}{ AAR DAY 19} & Between Groups & 0.0271 & 2 & 0.0136 & 5.72 & $0.00 *$ \\
\hline & Within Groups & 0.4511 & 190 & 0.0024 & & \\
\hline & Total & 0.4783 & 192 & & & \\
\hline
\end{tabular}

$* \& * *$ indicate significance at $1 \% \& 5 \%$ respectively. The ANOVA results for all the other sample days are available with the authors. 


\section{Conclusion}

The semi-strong form of market efficiency suggests that stock prices reflect all material past and public information. Therefore, an investment strategy based on public information should not result in above average returns. To investigate the semi-strong form of market efficiency in the KSE, we investigated stock prices (returns) around dividend announcements including cash, stock, and simultaneous cash and stock dividend announcements.

The literature suggests that those firms who have viable investment opportunities should retain their cash and invest in such opportunities. Therefore, when firms declare cash dividends, it indicates the lack of such investment opportunities and should be considered negatively, i.e., resulting in negative abnormal returns. Further cash dividends reduce cash flows for reinvestment which results in reducing future cash dividends. Since the literature defines the price of any asset as equal to the present value of its expected future cash flows, the price of the stock should fall.

Another explanation is the tax dividend hypothesis, which holds that investors dislike cash dividends since they are taxable. It also implies that stock dividends should result in positive abnormal returns. However, it is also held that firms will declare dividends when future prospects are bright for the firm's operations and profitability, i.e., the signaling effect. Therefore, stock prices (returns) should react positively to cash dividend announcements. The literature also suggests that payment of extra cash as dividends to shareholders reduces agency conflicts and costs and hence should result in a positive response by the market.

We found that the reaction of stock prices to cash dividend announcements is statistically insignificant. The returns are mostly negative for the 41-day window, which might be attributed to the tax effect of cash dividends. However, the negative returns are partly compensated by the cash dividends to investors which were not included in the calculations of returns. Also, the $\mathrm{AABR}$ and $\mathrm{CAABR}$ for stock dividend announcements are statistically significant, suggesting a positive reaction. Stock dividends are not taxed and are resorted to by firms when cash needs are high and future operations require an expanded equity base. Moreover, capital gains in the equity market are not taxed in Pakistan. Hence stock dividends are perceived favorably by investors in the KSE.

The results for simultaneous cash and stock dividend announcements are similar to those for the stock dividend announcements, and reject the 
semi-strong form of market efficiency of the KSE. In simultaneous cash and stock dividends, an investor receives cash flows in the form of cash as well as additional stocks, i.e., capital gains from the company. This gives a very strong signal to investors regarding future growth in dividends and stock value. Therefore, such announcements are perceived positively and stock prices appreciate. However, it must be noted that the returns calculated for such announcements are net of cash dividends and if such dividends are included, the positive returns will further improve. 


\section{References}

Acker, D. (1999). Stock Return Volatility and Dividend Announcements. Review of Quantitative Finance and Accounting, 12, 221-242.

Adelegan, O.J. (2003). Capital Market Efficiency and the Effects of Dividend Announcements on Share Prices in Nigeria. African Development Review, 15, 218-236.

Aharony, J., and Dotan, A. (1994). Regular Dividend Announcements and Future Unexpected Earnings: An Empirical Analysis. The Financial Review, 29, 125-151.

Ali, S., and Akbar, M. (2009). Calendar Effects in Pakistani Stock Market. International Review of Business Research Papers, 5, 389-404.

Ali, S., and Mustafa, K. (2001). Testing Semi-Strong Form Efficiency of Stock Market. The Pakistan Development Review, 40, 651-674.

Below, S. D., and Johnson, K.H. (1996). An Analysis of Shareholder Reaction to Dividend Announcements in Bull and Bear Markets. Journal of Financial and Strategic Decisions, 9, 15-26.

Benartzi, S., Michaely, R., and Thaler, R. (1997). Do Changes in Dividends Signal the Future or the Past. The Journal of Finance, 52, 10071034.

Bhattacharya, S. (1979). Imperfect Information, Dividend Policy, and 'The Bird in the Hand' Fallacy. The Bell Journal of Economics, 10, 259270 .

Black, F. (1976). The Dividend Puzzle. Journal of Portfolio Management, 2, 5-8.

Brickley, J. (1983). Shareholder Wealth, Information Signaling and the Specially Designated Dividend. Journal of Financial Economics, 12, 187-209.

Chakraborty, M. (2006). Market Efficiency for the Pakistan Stock Market: Evidence from the Karachi Stock Exchange. South Asia Economic Journal, 7, 67-81. 
Charest, G. (1978). Dividend Information, Stock Returns and Market Efficiency II. Journal of Financial Economics, 6, 297-330.

Easterbrook, H. (1984). Two Agency Cost Explanations of Dividends. The American Economic Review, 74, 650-659.

Easton, A., and Sinclair, A. (1989). The Impact of Unexpected Earnings and Dividends on Abnormal Returns to Equity. Accounting \& Finance, 29, 1-19.

Fama, E. (1965). The Behavior of Stock Market Prices. Journal of Business, $38,34-105$.

Foster III, W., and Vickrey, D. (1978). The Information Content of Dividend Announcements. The Accounting Review, 53, 360-370.

Gordon, M. (1959). Dividend, Earning, and Stock Prices. The Review of Economics and Statistics, 41, 99-105.

Gordon, M. (1962). The Savings Investment and Valuation of a Corporation. The Review of Economics and Statistics, 44, 37-51.

Graham, R., and Dodd, P. (1951). Security Analysis. McGraw-Hill Book Company: New York.

Gunasekarage, A., and Power, D.M. (2006). Anomalous Evidence in Dividend Announcement Effect. Managerial Finance, 32, 209-226.

Healy, P., and Palepu, K. (1988). Earnings Information Conveyed by Dividend Initiations and Omissions. Journal of Financial Economics, $21,149-175$.

Hussain, F. (1998). Note: A Seasonality in the Pakistani Equity Market: The Ramadan Effect. The Pakistan Development Review, 37, 77-81.

Hussain, F. (1999). The Day of the Week Effect in the Pakistani Equity Market: An Investigation. The Lahore Journal of Economics, 5, 9398.

John, K., and Williams, J. (1985). Dividends, Dilution and Taxes: A Signaling Equilibrium. Journal of Finance, 40, 1053-1070. 
Kong, S., and Taghavi, M. (2006). The Effect of Annual Earnings Announcements on the Chinese Stock Markets. International Advances in Economic Research, 12, 318-326.

Lee, B. (1995). The Response of Stock Prices to Permanent and Temporary Shocks to Dividends. Journal of Financial and Quantitative Analysis, 30, 1-22.

Lintner, J. (1964). Optimal Dividends and Corporate Growth Under Uncertainty. The Quarterly Journal of Economics, 78, 49-95.

Lonie, A.A., Gunasekarage, A., Power, D.M., and Sinclair C.D. (1996). The Stock Market Reaction to Dividend Announcements: A UK Study of Complex Market Signals. Journal of Economic Studies, 23, 32-52.

Miller, H., and Modigliani, F. (1961). Dividend Policy, Growth and the Valuation of Shares. The Journal of Business, 34, 411-433.

Miller, M., and Rock, K. (1985). Dividend Policy Under Asymmetric Information. Journal of Finance, 40, 1031-1051.

Osei, K. (1998). Analysis of Factors Affecting the Development of an Emerging Capital Market: The Case of the Ghana Stock Market. African Economic Research Consortium Research Paper, No. 76.

Pettit, R. (1972). Dividend Announcements, Security Performance, and Capital Market Efficiency. The Journal of Finance, 27, 993-1007.

Reilly, F.K., and Brown, K.C. (2006). Investment Analysis and Portfolio Management, $8^{\text {th }}$ Edition, South Western Publishing Company.

Rozeff, S., and Kinney, R. (1976). Capital Market Seasonality: The Case of Stock Returns. Journal of Financial Economics, 3, 379-402.

Uddin, M.H., and Chowdhury, G.M. (2005). Effect of Dividend Announcement and Shareholders' Value: Evidence from Dhaka Stock Exchange. Journal of Business Research, 7, 61-72. 